\title{
Responses to a GP survey: current controversies in diet and cardiovascular disease
}

\author{
Bruce A. Griffin ${ }^{1}$ and John A. A. Nichols ${ }^{2^{*}}$ (D)
}

\begin{abstract}
Background: When advising patients on diet and health, the general practitioner (GP) makes judgements based on the evidence available. Since current evidence on diet and cardiovascular disease is conflicted and confusing, we surveyed the current consensus amongst GPs. The aim of this study was to determine the views of GPs on dietary saturated fat, carbohydrates and long chain omega-3 fatty acids in the management of cardiovascular disease.

Method: An online questionnaire inviting participants to comment on seven contentious statements on diet and cardiovascular disease. Questionnaire circulated to the 1800 members of South West Thames Faculty of the Royal College of General Practitioners (RCGP). Participants were invited to tick "Agree", "Disagree" or "Not sure" and were encouraged to add comments for each question. The results were analysed with a combination of statistical analysis and thematic analysis of comments.

Results: There were 89 responses. Most GPs seem well aware that drug treatment alone is inadequate and that dietary advice is important. However, there was considerable disagreement about the roles of saturated fats and carbohydrates in cardiovascular disease and "Not sure" responses ranged from 12 to 40.7\%. The 40. $7 \%$ related to a statement on long chain omega-3 fatty acids. Analysis of comments revealed more opinions including an awareness of the need to warn patients about trans-fatty acids.

Conclusions: Although the GP response rate was poor, responders do seem to see dietary advice as part of their role but do not consider themselves as experts. Education in this area should have a higher priority.
\end{abstract}

Keywords: Cardiovascular diseases, Primary health care, Nutrition science, Dietetics, Medical education

\section{How this fits}

General practitioners need to give advice on nutrition, diet and health, especially cardiovascular health concerns. There has been concern that medical school gives little if any time to these issues. This survey shows that there is a good deal of confusion in this area and our data suggest that most knowledge is gained through experience working in primary care.

\section{Background}

The average general practitioner (GP) in the United Kingdom (UK) will have received very little education at

\footnotetext{
* Correspondence: drjaan@ntlworld.com

${ }^{2}$ Department of Clinical Medicine and Ageing, University of Surrey, 60 Manor Way, Guildford, Surrey GU2 7RR, UK

Full list of author information is available at the end of the article
}

medical school on the role of nutrition in health and disease [1-3], but should be well versed in Pharmacology as a prescribing doctor. In a recent survey [2], only $33 \%$ of medical school academics felt that they were providing adequate teaching on nutrition and health. Therefore, GPs may feel more confident in providing advice on drug therapy rather than diet for the prevention of cardiovascular disease (CVD). However, an experienced GP may have acquired information about diet and lifestyle through their professional experience. Current controversies over the relevance of free sugars (as opposed to endogenous sugars in fruit (fructose) and milk (lactose)) and fats to the aetiology of CVD [4-6] has caused confusion amongst the general public $[7,8]$ and we wondered what the consensus was amongst GPs. Also, since 2013, the National Institute for Health and Care Excellence (NICE) clinical guidelines have de-emphasised the

(c) The Author(s). 2018 Open Access This article is distributed under the terms of the Creative Commons Attribution 4.0 International License (http://creativecommons.org/licenses/by/4.0/), which permits unrestricted use, distribution, and 
role of long chain omega-3 fatty acids in the management of CVD and advise against routine prescribing of omega-3 acid ethyl esters (Omacor) [9]. However, NICE continue to recommend an increase in dietary fish as part of a Mediterranean diet [9]. There is a substantial body of evidence for benefits to both primary and secondary cardiovascular health from long chain omega-3 [10-13], and an equally impressive body of evidence that has influenced NICE to be cautious [14-16]. A 2017 study lasting 19 years has shown a lower CVD death rate (hazard ratio 0.73 ) in subjects taking a long term regular daily dose of a long chain omega-3 fatty acid supplement [17].

The aim of our study was to assess the views of GPs on a range of issues relating to nutrition and cardiovascular disease by measuring their response to several emotive and contentious questions about diet and health.

\section{Methods}

A survey monkey questionnaire was sent by email to 1800 GPs in the SW Thames section of the RCGP. One follow-up reminder was sent with a link to the questionnaire as recommended by Pealer et al. [18]. This was followed by asking non-responders to complete the same questionnaire at an NHS Clinical Commissioning Group (CCG) meeting for all GPs in the Guildford and Waverly area of Surrey (approximately 6\% of SW Thames GPs). The questions were framed as tests of opinion rather than tests of knowledge with tick box options "Agree", "Disagree" and "Not sure". Participants were also encouraged to add comments and the comments were analysed using thematic analysis.

Questions:

1. Once you start a patient on a statin, diet isn't very important.

2. Omega 3 intake is key to recovery from a cardiac event.

3. LDL cholesterol is more important than HDL cholesterol when interpreting a lipid profile.

4. The latest evidence on dietary fat means that we can now advise that it is safe to consume saturated fat-rich foods.

5. Diet and dyslipidaemia are linked to dysfunction of the endothelium.

6. Non-alcoholic fatty liver disease is a major risk factor for cardiovascular disease.

7. Dietary carbohydrates are neutral with respect to cardiovascular disease.

\section{Statistics}

The completed questionnaires were analysed using chisquared foursome tables to determine differences between internet responders and non-responders and calculate $p$ values. IBM SPSS Statistics software was used to analyse gender differences, significance of years in general practice using the student $\mathrm{t}$-test and correlation coefficients to show any correlations between different components of the questionnaire and to calculate $p$ values for this data. An analysis of respondents' comments was made for recurrent themes.

\section{Results}

A total of 89 GPs responded to the initial questionnaire and a further 19 non-responders completed the questionnaire at the CCG meeting. The total sample was 108 , which was $6 \%$ of the targeted GPs.

There were 74 (68.5\%) female GPs and 33 (30.5\%) male GPs. Although age was not recorded for participants the number of years in general practice was recorded. The significance of age and experience was reflected in this data (Additional file 1: Appendix 1). The mean number of years in general practice was $13.7 \mathrm{yrs}$. (range 0.5-42) and for male GPs average was 17.6 yrs. (range 2-42) and for female GPs average was 12 yrs. (range 0.5-33). This data was similar to regional data for age and gender for GPs in South England although there was a slight bias in favour of female GPs responding to the questionnare which failed to reach statistical significance (Additional file 2: Appendix 2).

The combined results are summarised in Table 1 . There was no statistically significant difference between internet responders and non-responders. However there was a trend for Question 2 with a greater proportion of non-responders disagreeing with the statement "Omega 3 intake is key to recovery from a cardiac event": Responders disagreed 30/89 (33.7\%) Non responders disagreed 10/19 (52.6\%), $p=0.076$. Responders were twice as likely to respond "Not sure" than non-responders:

Responders "not sure" 40/89 (44.9\%) and non-responders "not sure" 4/19 (21.1\%), $p=0.054$.

Table 1 Summary of results from questionnaire

\begin{tabular}{|c|c|c|c|}
\hline Questions & Agree & Disagree & Not sure \\
\hline $\begin{array}{l}\text { 1. Diet is unimportant for patients } \\
\text { on statins }\end{array}$ & $3(2.8 \%)$ & $\begin{array}{l}105 \\
(97.2 \%)\end{array}$ & $0(0 \%)$ \\
\hline $\begin{array}{l}\text { 2. Omega-3 relevant to } \\
\text { cardiac events }\end{array}$ & $24(22.2 \%)$ & $40(37 \%)$ & $\begin{array}{l}44 \\
(40.7 \%)\end{array}$ \\
\hline 3. LDL more important than $\mathrm{HDL}$ & $49(45.4 \%)$ & $42(38.9 \%)$ & $\begin{array}{l}17 \\
(15.7 \%)\end{array}$ \\
\hline 4. Dietary saturated fat safe & $18(16.7 \%)$ & $57(52.8 \%)$ & $\begin{array}{l}33 \\
(30.6 \%)\end{array}$ \\
\hline $\begin{array}{l}\text { 5. Endothelial dysfunction } \\
\text { and dyslipidaemia }\end{array}$ & $80(74.1 \%)$ & $3(2.8 \%)$ & $\begin{array}{l}26 \\
(24.1 \%)\end{array}$ \\
\hline 6. NAFLD major risk factor for CVD & $77(71.3 \%)$ & $6(5.6 \%)$ & $\begin{array}{l}26 \\
(24.1 \%)\end{array}$ \\
\hline $\begin{array}{l}\text { 7. Dietary carbohydrates neutral } \\
\text { for CVD }\end{array}$ & $11(10.2 \%)$ & $84(77.8 \%)$ & $13(12 \%)$ \\
\hline
\end{tabular}


Table 2 Gender trend for response: not sure

\begin{tabular}{|c|c|c|c|c|}
\hline Questions & $\begin{array}{l}\text { Female } \\
(n=74)\end{array}$ & $\begin{array}{l}\text { Female } \\
\%\end{array}$ & $\begin{array}{l}\text { Male } \\
(n=33)\end{array}$ & $\begin{array}{l}\text { Male } \\
\%\end{array}$ \\
\hline $\begin{array}{l}\text { 1. Statins more important } \\
\text { than diet }\end{array}$ & 0 & $0 \%$ & 0 & $0 \%$ \\
\hline $\begin{array}{l}\text { 2. Omega-3 relevant to } \\
\text { cardiac events }\end{array}$ & $34^{\mathrm{b}}$ & $45.9 \%$ & $9^{\mathrm{b}}$ & $27.3 \%$ \\
\hline $\begin{array}{l}\text { 3. LDL more important } \\
\text { than HDL }\end{array}$ & 11 & $14.9 \%$ & 6 & $18.2 \%$ \\
\hline 4. Dietary saturated fat safe & $26^{a}$ & $35.1 \%$ & $6^{\mathrm{a}}$ & $18.2 \%$ \\
\hline $\begin{array}{l}\text { 5. Endothelial dysfunction \& } \\
\text { dyslipidaemia }\end{array}$ & 21 & $28.4 \%$ & 4 & $12.1 \%$ \\
\hline $\begin{array}{l}\text { 6. NAFLD major risk factor } \\
\text { for CVD }\end{array}$ & 17 & $24.2 \%$ & 8 & $23.0 \%$ \\
\hline $\begin{array}{l}\text { 7. Dietary carbohydrates neutral } \\
\text { for CVD }\end{array}$ & 11 & $14.9 \%$ & 2 & $6.1 \%$ \\
\hline
\end{tabular}

${ }^{a}$ Significant gender difference at $p<0.05$

${ }^{\mathrm{b}}$ Borderline non-significant gender difference at $p=0.07$

There was a trend for female GPs to be more likely to chose "Not sure" responses (Table 2), but this was only statistically significant for Question 4 which suggested that dietary saturated fat is now considered "safe". 78.8\% of male GPs disagreed with this statement, whereas only $41.9 \%$ of female GPs disagreed and 35\% were "Not sure."

There was a trend for years in practice as a GP to be a factor in responses to the statements about omega- 3 and cardiac events, interpretation of lipid profiles and nonalcoholic fatty liver disease with responses from younger GPs reflecting their lack of experience (Table 3). There was a degree of overlap between questions which did not reach statistical significance: $42.6 \%$ disagreed that dietary carbohydrates are neutral for CVD and disagreed that it is now safe to advise saturated fat rich food and $42.6 \%$ agreed that diet \& dyslipidaemia are linked to endothelial dysfunction and were of the opinion that dietary saturated fat is not safe.

Table 3 Years as a GP influence on responses

\begin{tabular}{|c|c|c|c|}
\hline $\begin{array}{l}\text { Question } \\
\text { numbers }\end{array}$ & & & $p$ values \\
\hline Q3 & $\begin{array}{l}\text { Omega-3 relevant } \\
\text { to cardiac events }\end{array}$ & $\begin{array}{l}\text { "Agree" sub-group had been } \\
\text { mean of } 5 \text { yrs. longer as a GP } \\
\text { than "Disagree" sub-group }\end{array}$ & 0.17 \\
\hline Q2 & $\begin{array}{l}\text { LDL more } \\
\text { important than } \\
\text { HDL }\end{array}$ & $\begin{array}{l}\text { "Unsure" sub-group had been } \\
\text { mean of } 6 \text { yrs. longer as a GP } \\
\text { than "Agree" and "Disagree" } \\
\text { combined }\end{array}$ & 0.057 \\
\hline Q5 & $\begin{array}{l}\text { Dyslipidaemia } \\
\text { linked to } \\
\text { endothelial } \\
\text { dysfunction }\end{array}$ & $\begin{array}{l}\text { "Disagree" ( } n=3) \text { were recent } \\
\text { recruits to GP with mean of } \\
5.8 \mathrm{yr} \text {. as a GP }\end{array}$ & 0.15 \\
\hline Q6 & $\begin{array}{l}\text { NAFLD major risk } \\
\text { factor for CVD }\end{array}$ & $\begin{array}{l}\text { "Disagree" }(n=6) \text { were recent } \\
\text { recruits to GP with mean of } \\
6.9 \text { yrs. as a GP }\end{array}$ & 0.1 \\
\hline $\begin{array}{l}\text { Questions } \\
1,4,7\end{array}$ & & $\begin{array}{l}\text { Years as GP were } \\
\text { not significant }\end{array}$ & - \\
\hline
\end{tabular}

Although there was an even split for statement 3 on the relative importance of HDL and LDL cholesterol with $15.7 \%$ of respondents opting for "not sure" (Table 1), $5.6 \%$ added the comment that the $\mathrm{HDL} /$ cholesterol ratio is more significant.

Subjects were invited to add comments to all questions and at the end of the questionnaire. There were 37 comments that varied from very brief such as "in moderation" for the question on safety of saturated fats, to longer detailed comments on the role of nutrition science in primary care. Comments of 4 words or less that conveyed little or no meaning, were excluded (5/37). Comments that could be classified thematically (32/37) tended to come from respondents who had been GPs a little longer (Table 4).

From a total of 32 such comments, the commonest comment (10/32) was an acknowledgement that a wide range of nutrients are important to cardiovascular health, and that a pharmacological approach alone is inadequate. Comments that are representative examples of each type of response are summarised in Table 5.

\section{Discussion}

\section{Summary}

Comments by participants (Table 5) seem to show a genuine interest in dietary factors that influence cardiovascular disease (CVD). Most GPs (97\%) were well aware that diet is of crucial importance in the control of CVD (Tables 1 and 5). However, there was considerable confusion about certain aspects of this topic with $44 \%$ being "Not sure" about the role of omega-3 in recovery from cardiovascular events, and $33 \%$ being unsure what advice they should be giving on the safety of saturated fats in the diet ( $35 \%$ for female GPs). The lack of teaching on nutritional science in medical schools is illustrated by some responses from new recruits to general practice (Tables 3 and 4).

The uncertainty and doubts about the evidence regarding the heart and long chain omega-3 supplementation is illustrated by a response to the Question 2; "Omega-3 is key to recovery from a cardiac event" with the comment: "If it was, why was it taken off prescriptions?", whereas others were impressed with the evidence for the anti-arrhythmic and anti-thrombotic activity of dietary long chain omega- 3 fatty acids. Although controversial, there is good evidence for the anti-arrhythmic and anti-thrombotic properties of

Table 4 Number of years as a GP Versus type of comment or no comment

\begin{tabular}{lllll}
\hline $\begin{array}{l}\text { Type of } \\
\text { comments: }\end{array}$ & N & $\begin{array}{l}\text { Mean years as a } \\
\text { GP }\end{array}$ & $\begin{array}{l}\text { Std. } \\
\text { Deviation }\end{array}$ & $\begin{array}{l}\text { Std. Error } \\
\text { Mean }\end{array}$ \\
\hline $\begin{array}{l}\text { None or insignificant } \\
\text { Significant }\end{array}$ & 76 & 13.2 & 9.7196 & 1.1149 \\
\hline
\end{tabular}

$\chi^{2}$ test: $p=0.038$ 
Table 5 Analysis of participant's comments

\begin{tabular}{|c|c|c|c|}
\hline Topic of comments & $\begin{array}{l}\text { Number of } \\
\text { comments }\end{array}$ & $\begin{array}{l}\text { Questions } \\
\text { comments related to }\end{array}$ & One good representative example of comments from this category \\
\hline $\begin{array}{l}\text { General value of diet in } \\
\text { cardiovascular health. }\end{array}$ & 10 & $\begin{array}{l}\text { Q1 and final } \\
\text { comment }\end{array}$ & $\begin{array}{l}\text { Even if it has less effect on lipids than the statin, diet is still } \\
\text { important in other areas of cardiovascular health. }\end{array}$ \\
\hline $\begin{array}{l}\text { Trans fatty acids an } \\
\text { important risk factor. }\end{array}$ & 7 & $\begin{array}{l}\text { Qs 3, 4, } 5 \text { and } \\
\text { final comment }\end{array}$ & $\begin{array}{l}\text { Excess saturated fat, cholesterol and trans-fats all increase the risk } \\
\text { of CVD. }\end{array}$ \\
\hline $\begin{array}{l}\text { Refined sugar an important } \\
\text { risk factor }\end{array}$ & 7 & $\begin{array}{l}\text { Qs } 4,7 \text { and final } \\
\text { comments }\end{array}$ & $\begin{array}{l}\text { Complex carbohydrates have a beneficial effect and refined sugar } \\
\text { the opposite. }\end{array}$ \\
\hline $\begin{array}{l}\mathrm{HDL} / \text { cholesterol ratio is the } \\
\text { best guide }\end{array}$ & 6 & Q3 & $\begin{array}{l}\text { Both } \mathrm{HDL} \text { and } \mathrm{LDL} \text { are equally relevant. The ratio between them is } \\
\text { important. }\end{array}$ \\
\hline $\begin{array}{l}\text { References to diet and } \\
\text { metabolic syndrome }\end{array}$ & 5 & $\begin{array}{l}\text { Qs } 6,7 \text { and final } \\
\text { comments }\end{array}$ & $\begin{array}{l}\text { Carbohydrates are negative in that they contribute to the metabolic } \\
\text { syndrome and DM }\end{array}$ \\
\hline Low Gl diet is beneficial & 3 & Q7 & A high Gl diet has been shown to be a risk factor for CVD \\
\hline $\begin{array}{l}\text { Sugar can be converted } \\
\text { to fat }\end{array}$ & 3 & Q7 & $\begin{array}{l}\text { High intake of refined sugar leads to dyslipidaemia with sugar } \\
\text { converted to fat }\end{array}$ \\
\hline $\begin{array}{l}\text { GPs need more nutrition } \\
\text { knowledge }\end{array}$ & 3 & Final comments & I wish we doctors had more access to education related to nutrition \\
\hline $\begin{array}{l}\text { Advise patients to eat more } \\
\text { plant foods }\end{array}$ & 2 & Q4 & The main source of fats should be plant rather than animal derived. \\
\hline $\begin{array}{l}\text { High homocysteine is a risk } \\
\text { factor for CVD }\end{array}$ & 1 & Final comments & $\begin{array}{l}\text { Excess protein in the diet is an important risk factor, especially excess } \\
\text { methionine from cheese. It leads to high homocysteine levels. }\end{array}$ \\
\hline $\begin{array}{l}\text { VLDL cholesterol is an } \\
\text { important risk factor }\end{array}$ & 1 & Q3 & LDL is more important than HDL but VLDL cholesterol is even more so. \\
\hline $\begin{array}{l}\text { Role of omega-3 in prevent } \\
\text { ing CVD deaths }\end{array}$ & 1 & Q2 & $\begin{array}{l}\text { Omega } 3 \text { is anti-thrombotic and anti-arrhythmic. Synthetic supplements } \\
\text { have been disappointing. }\end{array}$ \\
\hline
\end{tabular}

long chain omega-3 fatty acids [10-13]. However, there was an impression of general confusion rather than an informed consensus on this issue amongst these GPs.

While dietary trans-fatty acids were not mentioned in the questionnaire, six GPs commented on the importance of these fatty acids as a risk factor for CVD. There was some agreement on the role of dietary free sugars and saturated fats in CVD with $42.6 \%$ of GPs disagreeing with both the statement that dietary saturated fat is safe (Q4), and that dietary carbohydrates are neutral for CVD (Q7). Several comments highlighted the importance of the differences between free sugars (as a CVD risk factor) and complex carbohydrates, with the latter being generally viewed as being beneficial to cardiovascular health.

The split vote on the relative importance of LDL cholesterol and HDL cholesterol, probably reflects the current state of knowledge and confusion over the questionable clinical relevance of raised HDL cholesterol. However one participant suggested that the circulating level of VLDL (very low density lipoprotein) is more significant than either LDL or HDL. This may well be relevant to patients with cardiometabolic risk factors who are at risk of developing metabolic syndrome and type 2 diabetes mellitus and in whom serum LDL cholesterol is unremarkable. Although VLDL is not generally available for testing in primary care, estimation of $12 \mathrm{~h}$ fasting triacylglycerol (also termed triglycerides) is available and would be as reliable as VLDL as an indicator of cardiometabolic risk [19].

The overall outcome of this survey provides evidence of a body of professional doctors who have vested interest in diet and health. However, as several GPs indicated, their knowledge of the topic is inadequate and this may apply especially in the early stages of their career.

\section{Strengths and limitations}

Strengths of this study include canvassing of grass roots GPs who are dealing with the issue of diet and CVD regularly. The main weakness of the study is the poor response rate to the initial e-mailed online survey monkey with only 89 (5.9\% of targeted group) responding. However, this response rate is fairly typical for mailings to members of the RCGP. A recent election for places on the college council got an $8.4 \%$ response (personal communication from Professor Kamila Hawthorne). While these responders may represent a select group of GPs with a greater interest in nutrition, there was very little difference between the responders and the 19 non-responders. An exception was that more responders disagreed about the value of long chain omega-3 fatty acids for recovery from a cardiac event than non-responders (52.6\% versus $33.7 \%, p=0.076)$. Responders were twice as likely to opt for "Not sure" for this statement. 


\section{Comparison with existing literature}

Previous research in this area is limited to the teaching of nutritional science for medical students and associated academic departments [1-3], but tends to be in accord with the impression from this trial that teaching of nutritional science both in medical school and after medical school is inadequate.

\section{Implications for future research}

To get an accurate assessment of the needs of GPs in relation to teaching on nutrition and health, a larger sample is needed. However, adequate coverage of this topic could be ensured by starting with focus groups to determine the best questions and format to use for any future research.

\section{Conclusions}

GPs see dietary advice as part of their role, but do not consider themselves as experts. Despite the poor response rate, the value of this paper is that it can inform those designing diet/CVD related interventions for GP settings as it highlights information needs of GPs and maybe also practice nurses who are likely to deliver most of this care. The uncertainty about the interpretation of the nutrition science that underlies many of the diet-related issues that GPs experience could, perhaps, be rectified by raising the profile of nutrition on the curriculum in medical schools $[1,2]$.

\section{Additional files}

Additional file 1: Appendix 1. Complete summary of trial data (raw study data used in SPSS analysis downloaded into an Excel file and edited to improve comprehension). (XLSX $20 \mathrm{~kb}$ )

Additional file 2: Appendix 2. Comparator data on Southern England GPs from other sources (data on age and gender balance from RCGP and government sources and statistical tests to show how they compared with our respondents). (DOCX $46 \mathrm{~kb}$ )

\section{Abbreviations}

CVD: Cardiovascular disease; GP: General practitioner; HDL: High density lipoprotein; LDL: Low density lipoprotein; RCGP: Royal College of general Practitioners

\section{Acknowledgements}

The collaboration of Katie Biring of the RCGP in finalising and circulating the online web questionnaire was much appreciated.

\section{Funding}

The electronic survey was supported and funded by the SW Thames Faculty of the RCGP. We worked with the faculty board to launch the web questionnaire through the official channels of the Royal College of General Practitioners at their central offices in London. The faculty administrator collected the results of the questionnaire and emailed them to us for further analysis.

Availability of data and materials

Full data is available as an Excel spreadsheet (Additional file 1: Appendix 1).

\section{Authors' contributions}

JAAN conceived the idea and devised the online questionnaire in collaboration with BAG and analysed the results of the questionnaire and wrote the first draft of the paper. He also found a sample of non-responders and recruited them to complete the same questionnaire. BAG is a professor of human nutrition and was able to give expert advice on the questionnaire. He also read the first draft and suggested amendments and additions to it. Both authors read and approved the final manuscript.

\section{Ethics approval}

Patient participation was not involved and this was an anonymised questionnaire for general medical practitioners (GPs). Therefore, after referring to the NHS Health Research Authority we deemed it unnecessary to seek ethical approval.

\section{Consent for publication}

Not applicable.

\section{Competing interests}

The authors declare that they have no competing interests.

\section{Publisher's Note}

Springer Nature remains neutral with regard to jurisdictional claims in published maps and institutional affiliations.

\section{Author details}

${ }^{1}$ Department of Nutritional Science, University of Surrey, Guildford, UK. ${ }^{2}$ Department of Clinical Medicine and Ageing, University of Surrey, 60 Manor Way, Guildford, Surrey GU2 7RR, UK.

Received: 18 May 2018 Accepted: 20 August 2018

Published online: 31 August 2018

\section{References}

1. Powell-Tuck J, Summerbell C, Garrow JS. Four years' experience of an undergraduate medical nutrition course. J Roy Soc Med. 1997;90(2):67-72.

2. Long W, Neild P. Nutrition training in UK medical undergraduate programmes - has the situation improved? Gut. 2016;65(1):A1-A310. PTH113

3. Womersley K, Ripullone K. Medical schools should be prioritising nutrition and lifestyle education. BMJ. 2017;359(j4861):148-9.

4. Dehghan M, Mente A, Zhang X, Swaminathan S, Li W, et al of the Prospective Urban Rural Epidemiology (PURE) study investigators. Associations of fats and carbohydrate intake with cardiovascular disease and mortality in 18 countries from five continents (PURE): a prospective cohort study. Lancet 2017;390: 2050-2062.

5. Ramsden CE, Domenichiello AF. PUR study challenges the definition of a healthy diet: but key questions remain. Lancet. 2017;390:2018-9.

6. Wang DD, Hu FB. Dietary fat and risk of cardiovascular disease: recent controversies and advances [review]. Annu Rev Nutr. 2017:37:423-46.

7. Liu AG, Ford NA, Hu FB, Zelman KM, Mozaffarian D, Kris-Etherton PM. A healthy approach to dietary fats: understanding the science and taking action to reduce consumer confusion. Nutr J. 2017;16:53.

8. Cookson C. Studies confuse public debate on healthy eating, say experts. Financial Times Newspaper. https:/www.ft.com/content/e9acd9b0-a5e011e3-b9ed-00144feab7de?segmentld=9b41d47b-8acb-fadb-7c7037ee589b60ab. Accessed 26 Aug 18.

9. NICE Guidelines. Myocardial infarction: cardiac rehabilitation and prevention of further cardiovascular disease. 2013. https:/www.nice.org.uk/search?q= myocardial+infarction\%3A+cardiac+rehabilitation. Accessed 26 Aug 2018.

10. Leaf A, Albert CM, Josephson M, Steinhaus D, Kluger J, Kang JX, Cox B, Zhang H, Schoenfeld D, Fatty Acid Antiarrhythmia Trial Investigators. Prevention of fatal arrhythmias in high-risk subjects by fish oil n-3 fatty acid intake. Circulation. 2005;112(18):2762-8.

11. Kromhout D, Geleijnse JM, de Goede J, Oude Griep LM, Mulder BJ, de Boer MJ, Deckers JW, Boersma E, Zock PL, Giltay EJ. n-3 fatty acids, ventricular arrhythmia-related events, and fatal myocardial infarction in postmyocardial infarction patients with diabetes. Diabetes Care. 2011;34(12):2515-20.

12. Cao Y, Lu L, Liang J, Liu M, Li X, Sun R, Zheng Y, Zhang P. Omega-3 fatty acids and primary and secondary prevention of cardiovascular disease [review]. Cell Biophys. 2015;72(1):77-81. 
13. Wang Q, Liang X, Wang L, Lu X, Huang J, Cao J, Li H, Gu D. Effect of omega-3 fatty acids supplementation on endothelial function: a metaanalysis of randomized controlled trials [review]. Atherosclerosis. 2012;221(2): 536-43.

14. Khoueiry G, Abi Rafeh N, Sullivan E, Saiful F, Jaffery Z, Kenigsberg DN, Krishnan SC, Khanal S, Bekheit S, Kowalski M. Do omega-3 polyunsaturated fatty acids reduce risk of sudden cardiac death and ventricular arrhythmias? A meta-analysis of randomized trials. Heart Lung. 2013;42(4):251-6.

15. Billman GE. The effects of omega-3 polyunsaturated fatty acids on cardiac rhythm: a critical reassessment [Review]. Pharmacol Ther. 2013;140(1):53-80.

16. Higgins JPT, Capps NE, Riemersma RA, Ebrahim SBJ, Ness AR, Moore HJ, Worthington HV, Durrington PN, Hooper L, Thompson RL, Harrison RA, Summerbell CD. Risks and benefits of omega 3 fats for mortality, cardiovascular disease, and cancer: systematic review. BMJ. 2006;332:752-60.

17. Lentjes $\mathrm{MAH}$, Keogh RH, Welch AA, et al. Longitudinal associations between marine omega-3 supplement users and coronary heart disease in a UK populationbased cohort. BMJ Open. 2017;7:e017471. https://doi.org/10.1136/ bmjopen-2017-017471.

18. Pealer $L N$, et al. The feasibility of a web-based surveillance system to college health risk behaviour. Health Ed Behav. 2001;28:547-59.

19. Libby P. Triglycerides on the rise: should we swap seats on the seesaw? [review]. Eur Heart J. 2015:36(13):774-6.

Ready to submit your research? Choose BMC and benefit from:

- fast, convenient online submission

- thorough peer review by experienced researchers in your field

- rapid publication on acceptance

- support for research data, including large and complex data types

- gold Open Access which fosters wider collaboration and increased citations

- maximum visibility for your research: over $100 \mathrm{M}$ website views per year

At $\mathrm{BMC}$, research is always in progress.

Learn more biomedcentral.com/submissions 